\title{
Fluorometric Assessment of Sulfhydryl Oxidase Activity: Optimization by Response Surface Methodology
}

mahmoud hussein hadwan ( $\triangle$ mahmoudhadwan@gmail.com )

Babylon university https://orcid.org/0000-0003-1958-7764

Abdul Razzaq S. Alsalman

University of Babylon College of Medicine

Lamia A. Almashhedy

University of Babylon

Abdulsamie H. Alta'ee

University of Babylon College of Medicine

Asad M. Hadwan

University of Al-Qadisiyah College of Education

\section{Research Article}

Keywords: Sulfhydryl Oxidase, Response surface methodology, Hematin, Hemoglobin,

Spectrofluorometric Assessment

Posted Date: August 17th, 2021

DOI: https://doi.org/10.21203/rs.3.rs-781070/v1

License: (c) (1) This work is licensed under a Creative Commons Attribution 4.0 International License.

Read Full License

Version of Record: A version of this preprint was published at Journal of Fluorescence on December 2nd, 2021. See the published version at https://doi.org/10.1007/s10895-021-02861-7. 


\title{
Fluorometric Assessment of Sulfhydryl Oxidase Activity: Optimization by Response Surface Methodology
}

\author{
Mahmoud H. Hadwan ${ }^{*}$, Abdul Razzaq S. Alsalman², Lamia A. Almashhedy ${ }^{1}$, Abdulsamie H. Alta'ee ${ }^{2}$, \\ Asad M. Hadwan ${ }^{3}$ \\ ${ }^{1}$ Chemistry Department, College of Science, University of Babylon, Hilla, Iraq. \\ ${ }^{2}$ College of Medicine, University of Babylon, Hilla, Iraq. \\ ${ }^{3}$ Chemistry Department, College of Education, University of Al-Qadisiyah, Iraq. \\ * (Corresponding author) \\ Email address: \\ MHHadwan: mahmoudhadwan@gmail.com
}

AR Alsalman: abdulrazzaqalameri@yahoo.com

LAAlmashhedy: dr.lamia71@yahoo.com

AHAlta'ee: $\underline{\text { abdulsamie68@gmail.com }}$

AMHadwan: asadhadwan95@gmail.com

\begin{abstract}
Sulfhydryl oxidase was studied using a spectrofluorometric assay. The current protocol operates by using a combination of hemoglobin (HB) and hematin (HT) as a peroxidase mimic to catalyze the $\mathrm{H}_{2} \mathrm{O}_{2}$-dependent oxidation of thiamine. The response surface methodology is used to optimize the new method (RSM). The current method is very accurate, sensitive, and linear up to $200 \mathrm{IU}$. When compared to the colorimetric method, the method produced a satisfactory correlation. The novel protocol is being used to evaluate asthenospermic patients' and fertile men's seminal SHO activity. The current protocol was used to determine reference values for seminal sulfhydryl oxidase activity. Due to the fact the newly developed spectrofluorometric method is more sensitive and precise than other colorimetric methods, and because thiamine is less expensive than other types of probes used in colorimetric and spectrofluorometric methods, it is likely to find widespread use among scientists studying SHO activity in biological tissues. The present method's analytical recovery yielded high specific findings.
\end{abstract}

Keywords: Sulfhydryl Oxidase, Response surface methodology, Hematin, Hemoglobin, Spectrofluorometric Assessment. 


\section{Fluorometric Assessment of Sulfhydryl Oxidase Activity: Optimization by Response Surface Methodology}

\section{Graphical abstract:}

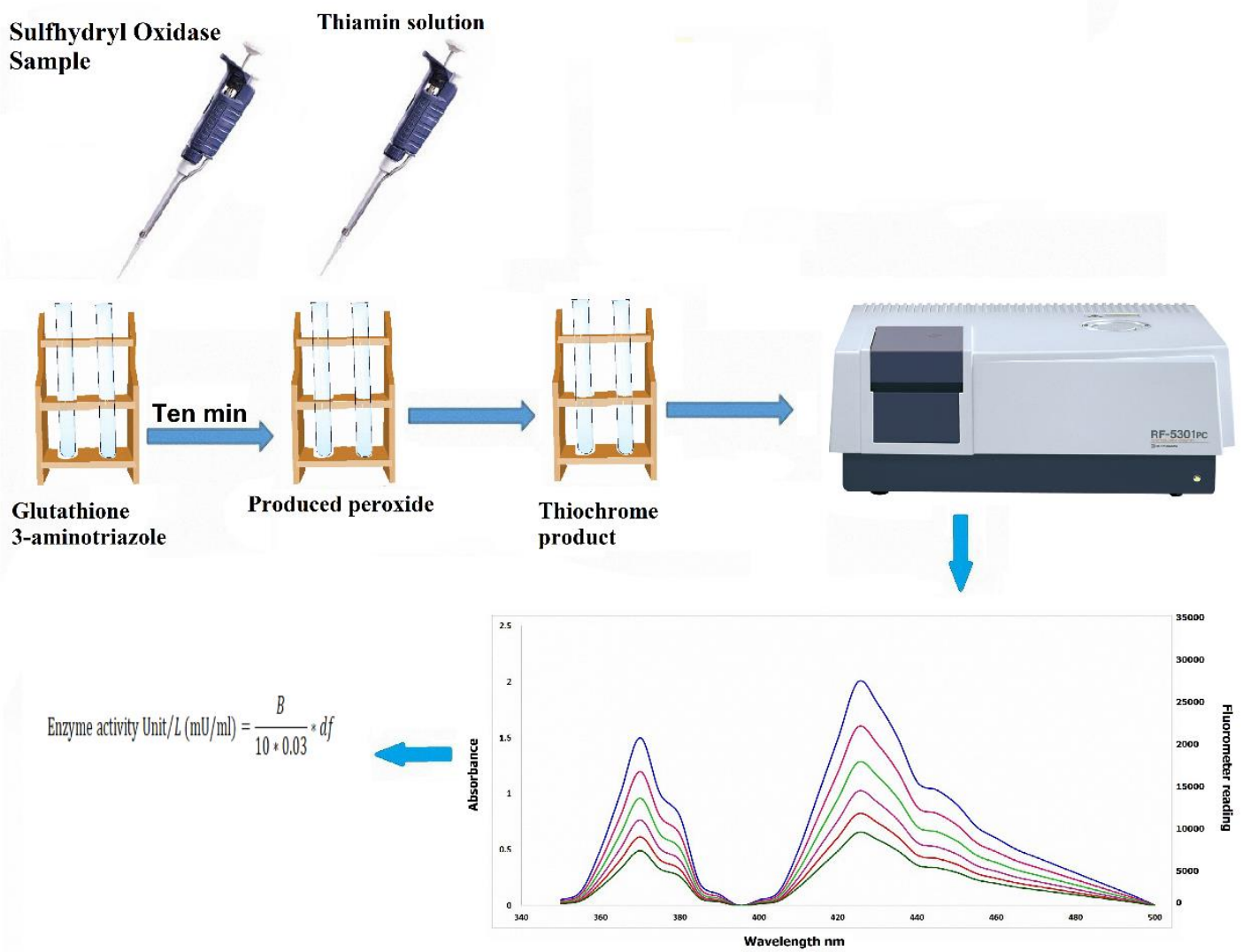




\section{Introduction}

The plasma thiol pool is principally composed of protein thiols, albumin thiols and slightly composed of thiols that have low-molecular-weight such as cysteine (Cys), homocysteine, $\gamma$-glutamylcysteine, cysteinylglycine and glutathione, [1]. Oxidation reactions always act to convert the reduced form of thiols (RSH) to the oxidized form (RSSR) via creating the disulphide bonds [2]. A disulphide bond has a covalent bond property and is also called a disulphide bridge or SS-bond. Under disorders of oxidative stress inclination, the oxidation process of Cys residues can form the reversible production of integrated disulphide bridges between low-molecular-mass thiols and protein thiol groups. Dynamic thiol-disulphide homeostasis is maintained via reduction of the formed disulphide bonds again to reduced thiol groups [3]. The status of dynamic thiol disulphide homeostasis has critical roles in detoxification, antioxidant protection, apoptosis, signal transduction, regulation of enzymatic activity and cellular signaling mechanisms and transcription factors [4]. Additionally, the homeostasis of dynamic thiol disulphide is progressively involved in many disorders. Several scientific reports indicate that an atypical thiol disulphide homeostasis state is implicated in the pathogenesis of some types of infertility such as asthenospermia [5].

The most important explanation for the thiol disulphide homeostasis comes from Chang and Morton's [6] study who discovered an exceptional enzyme thought to be involved in regulating the concentrations of sulfhydryl groups in the reproductive tract. A sulfhydryl oxidase acts to catalyze the production of disulfide bonds between sulfhydryl groups with the formation of hydrogen peroxide, as in the equation below:

$$
2 \mathrm{R}-\mathrm{SH}+\mathrm{O}_{2} \rightarrow \mathrm{R}-\mathrm{S}-\mathrm{S}-\mathrm{R}+\mathrm{H}_{2} \mathrm{O}_{2}
$$

Sulfhydryl oxidases include flavin adenine dinucleotide (FAD) as a prosthetic group. These enzymes have been recognized in animals [7], and plants [8]. Thiol oxidase is another enzyme concerned with the thiol disulphide homeostasis, this enzyme oxidizes thiol groups using oxygen as an electron acceptor, reducing it to water [9]. SHO acts to form the de novo disulfide bonds as a result, to reduce $\mathrm{SH}$ groups via enzymatic reduction of oxygen to form hydrogen peroxide. Moderate thiol levels are a necessary factor to maintain the defensive function and sperm motility and metabolism of spermatozoa under in vitro conditions [10].

The subsequent principles were utilized in the previous assays for SHO. The first utilize Ellman's reagent spectrophotometrically to monitor the disappearance of thiols by using discontinuous sampling [11, 12]. The disadvantages of this assay includes it is usability to detect the precise activity of SHO that is found in human seminal fluids, because it depends on monitoring small changes in a large background absorbance. Principally, the $\mathrm{K}_{\mathrm{m}}$ values for some thiol substrates reach more than $5 \mathrm{mM}$ [13].

The monitoring of oxygen consumption with polarography represents the second assay. This method is suitable and commonly applied for the estimation of 
sulfhydryl oxidase activity $[14,15]$. These methods have some disadvantages such as the absence of laboratory apparatus to achieve SHO activity in a large number of laboratories. Additionally, the monitoring of oxygen disappearance is achieved via an instrument that is fundamentally not very sensitive [13].

Raje et al, [13] established fluorometrical assay to measure SHO activity, which depends upon the dimerization of homovanillic acid (HVA) that is catalyzed by the peroxidase enzyme in the presence of hydrogen peroxide. This assay discounted the interference that results from the existence of the catalase enzyme in seminal fluids.

A new spectrofluorometric method was developed by utilizing the $\mathrm{H}_{2} \mathrm{O}_{2}$ dependent oxidation of dichlorofluorescein that catalyzed by peroxidase mimetic (a mixture of hematin (HT) and hemoglobin (HB) [16].

This paper describes a simple and accurate spectrofluorometric method. The assay is used peroxidase mimetic (a mixture of hematin (HT) and hemoglobin (HB)) to monitor the fluorometric $\mathrm{H}_{2} \mathrm{O}_{2}$-dependent oxidation of thiamine. Response surface methodology (RSM) was applied as a tool to optimize the new method.

\section{Principle}

SHO catalyzes the oxidation of reduced thiol to form disulfide bonds in the presence of molecular oxygen:

$$
2 \mathrm{R}-\mathrm{SH}+\mathrm{O}_{2} \rightarrow \mathrm{R}-\mathrm{S}-\mathrm{S}-\mathrm{R}+\mathrm{H}_{2} \mathrm{O}_{2}
$$

The assay is used peroxidase mimetic (a mixture of hematin (HT) and hemoglobin (HB)) to monitor the fluorometric $\mathrm{H}_{2} \mathrm{O}_{2}$-dependent oxidation of thiamine. The end product is called thiochrome, which has fluorescence property (at Ex/Em = $370 / 425 \mathrm{~nm}$ ). Aminotriazole (AT) is added to enzymatic reaction to inhibit catalase enzyme and prevents the consumption of hydrogen peroxide, as shown in fig (1). Since the intensity of fluorescence is directly proportional to SHO level; the SHO activity can be accurately measured. 


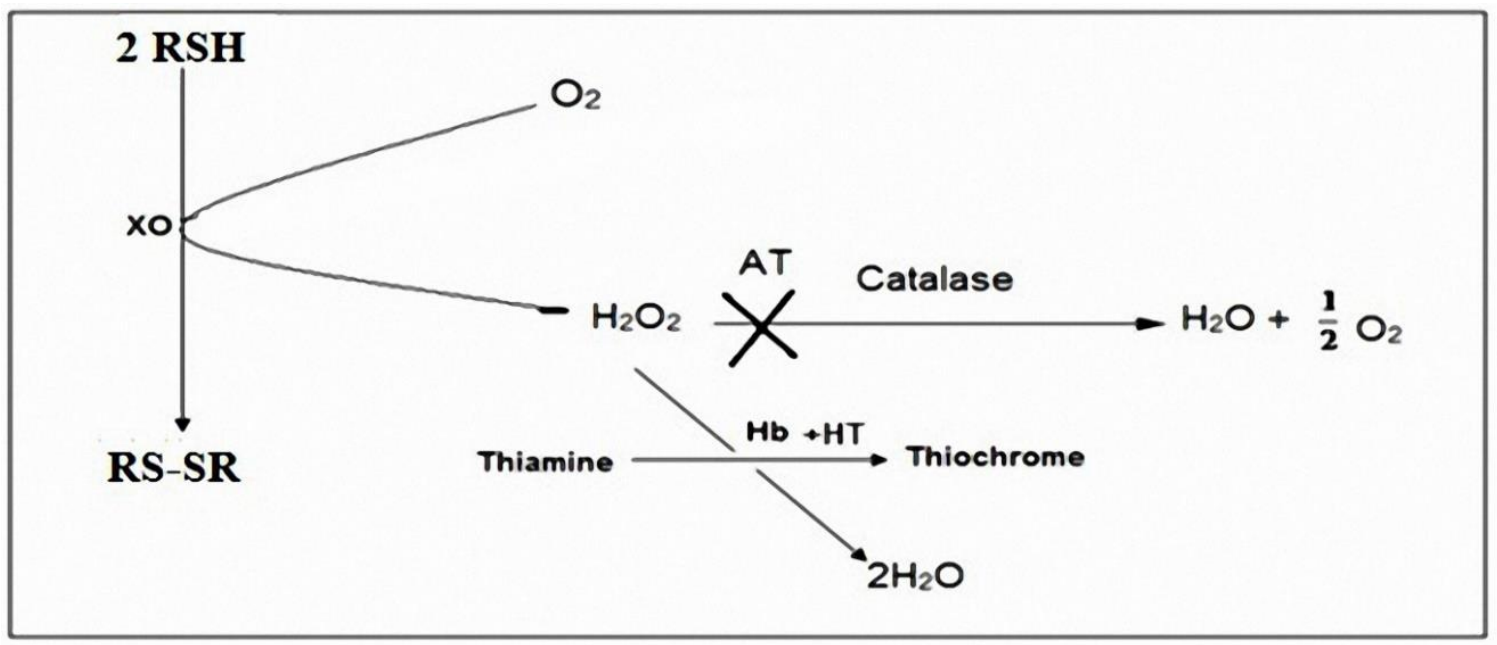

Figure 1. The details of the fluorometric assessment of sulfhydryl oxidase (SHO). peroxidase mimetic (a mixture of hematin (HT) and hemoglobin (HB)) to monitor the fluorometric $\mathrm{H}_{2} \mathrm{O}_{2}$-dependent oxidation of thiamine. 3-aminotriazole (AT) is involved in enzymatic reaction to eliminate the interference with catalase enzyme.

\section{Reagents}

A. Sodium hydroxide $(0.2 \mathrm{~N})$ is prepared by dissolving $0.8 \mathrm{~g}$ of $\mathrm{NaOH}$ in $100 \mathrm{~mL}$ of distilled water.

B. Hematin stock solution is composed of $0.05 \mathrm{~g}$ hematin that dissolved in $25 \mathrm{ml}$ of $0.2 \mathrm{~N}$ sodium hydroxide.

C. Hematin working solution is composed of $0.5 \mathrm{ml}$ of hematin stock solution that diluted to $50 \mathrm{ml}$ of $25 \mathrm{mM}$ sodium phosphate buffer (pH 7.4).

D. Hemoglobin $5 \times 10^{-7} \mathrm{M}$.

E. Peroxidase mimics solution is consisted of equal volumes of Hematin (HT) working solution and Hemoglobin (HB).

F. A phosphate buffer (100 mM; pH 7.0) was prepared by mixing solutions $\mathrm{a}$ and $\mathrm{b}$ at a ratio of 1:1.5. Solution (a) was prepared by dissolving $13.62 \mathrm{~g}$ of $\mathrm{KH}_{2} \mathrm{PO}_{4}$ in one liter of distilled water, and solution (b) was prepared by dissolving a $17.9 \mathrm{~g}$ of $\mathrm{Na}_{2} \mathrm{HPO}_{4} .2 \mathrm{H}_{2} \mathrm{O}$ in one liter of distilled water.

G. 3-aminotriazole (AT) $(50 \mathrm{mM})$ : is consisted of $0.42 \mathrm{gm}$ of 3-aminotriazole that is dissolved in $100 \mathrm{ml}$ of phosphate buffer solution ( $\mathrm{pH} 7.4$ ).

$\mathrm{H}$. Thiamin stock solution $(10 \mathrm{mM})$ is composed of $337 \mathrm{mg}$ of thiamine hydrochloride that is dissolved in $100 \mathrm{ml}$ of water. Refrigerated at $4{ }^{\circ} \mathrm{C}$.

I. Thiamin working solution $\left(2.5^{*} 10^{-3} \mathrm{M}\right)$ is composed of one volume of stock solution that is dissolved to four volumes with distilled water.

J. Glutathione solution $(300 \mu \mathrm{M})$ is composed of $0.1535 \mathrm{gm}$ of a GSH that is dissolved in a final volume of $100 \mathrm{ml}$ of $50 \mathrm{mM}$ phosphate buffer ( $\mathrm{pH} 7.5$ ) solution (bulb with $\mathrm{O}_{2}$ ).

K. Hydrogen peroxide $(200 \mu \mathrm{M})$ was prepared by suitable diluting of standard hydrogen peroxide (30\%) using a molar extinction coefficient of $43.6 \mathrm{M}^{-1} \mathrm{~cm}^{-1}$ at $240 \mathrm{~nm}$. This solution was freshly prepared and standardized daily. 


\section{Procedure}

Enzyme activity was measured according to the procedure described in Table 1:

Table 1. The details of the procedure that used for measuring the SHO enzyme activity.

\begin{tabular}{|c|l|l|l|l|l|l|l|l|}
\hline & Test & $\begin{array}{l}\text { Test } \\
\text { Blank }\end{array}$ & STD1 & STD2 & STD3 & STD4 & STD5 & $\begin{array}{l}\text { STD } \\
\text { Blank }\end{array}$ \\
\hline Sample & $30 \mu \mathrm{L}$ & -------- & ------- & ------- & ------- & ------- & ------- & -------- \\
\hline $\mathrm{H}_{2} \mathrm{O}_{2}$ STD & ------- & ------- & $30 \mu \mathrm{L}$ & $50 \mu \mathrm{L}$ & $100 \mu \mathrm{L}$ & $200 \mu \mathrm{L}$ & $300 \mu \mathrm{L}$ & ------- \\
\hline AT & $500 \mu \mathrm{L}$ & $500 \mu \mathrm{L}$ & $500 \mu \mathrm{L}$ & $480 \mu \mathrm{L}$ & $430 \mu \mathrm{L}$ & $330 \mu \mathrm{L}$ & $230 \mu \mathrm{L}$ & $530 \mu \mathrm{L}$ \\
\hline
\end{tabular}

Mix by inversion and equilibrate to $37^{\circ} \mathrm{C}$ for $5 \mathrm{~min}$. Then add:

\begin{tabular}{|c|l|l|l|l|l|l|l|l|}
\hline $\begin{array}{c}\text { GSH } \\
\text { solution }\end{array}$ & $400 \mu \mathrm{L}$ & $400 \mu \mathrm{L}$ & $400 \mu \mathrm{L}$ & $400 \mu \mathrm{L}$ & $400 \mu \mathrm{L}$ & $400 \mu \mathrm{L}$ & $400 \mu \mathrm{L}$ & $400 \mu \mathrm{L}$ \\
\hline
\end{tabular}

Mix by vortex and incubate for 10 minutes at $37^{\circ} \mathrm{C}$, after that, the reaction was terminated with $0.5 \mathrm{ml}$ of $8 \% \mathrm{TCA}$

Mix well and centrifuge for 15 minutes at $3000 \mathrm{xg}$, then remove $0.5 \mathrm{ml}$ of supernatant in a clean tube , and add:

\begin{tabular}{|l|l|l|l|l|l|l|l|l|}
\hline $\begin{array}{l}\text { Sodium } \\
\text { hydroxide }\end{array}$ & $500 \mu \mathrm{L}$ & $500 \mu \mathrm{L}$ & $500 \mu \mathrm{L}$ & $500 \mu \mathrm{L}$ & $500 \mu \mathrm{L}$ & $500 \mu \mathrm{L}$ & $500 \mu \mathrm{L}$ & $500 \mu \mathrm{L}$ \\
\hline Thiamine & $500 \mu \mathrm{L}$ & $500 \mu \mathrm{L}$ & $500 \mu \mathrm{L}$ & $500 \mu \mathrm{L}$ & $500 \mu \mathrm{L}$ & $500 \mu \mathrm{L}$ & $500 \mu \mathrm{L}$ & $500 \mu \mathrm{L}$ \\
\hline $\begin{array}{c}\text { Peroxidase- } \\
\text { mimics }\end{array}$ & $250 \mu \mathrm{L}$ & $250 \mu \mathrm{L}$ & $250 \mu \mathrm{L}$ & $250 \mu \mathrm{L}$ & $250 \mu \mathrm{L}$ & $250 \mu \mathrm{L}$ & $250 \mu \mathrm{L}$ & $250 \mu \mathrm{L}$ \\
\hline * Sample & ------ & $30 \mu \mathrm{L}$ & ------ & ----- & ----- & ----- & ------ & ------ \\
\hline
\end{tabular}

All the test tubes were mixed and leaved for $10 \mathrm{~min}$ at room temperature. All the solutions were transferred to suitable cuvettes and the fluorescent intensity were read (excitation, $370 \mathrm{~nm}$; emission, $425 \mathrm{~nm}$ ).

* Sample is added to test blank tube to omit the interference that arises from the presence of peroxides or peroxynitrate in semen samples with hydrogen peroxide that formed from the sulfhydryl oxidase catalyzed reaction.

$\Delta \mathrm{I}$ Standard $=$ I Standard - I Standard blank (I: intensity of fluorescence)

Plot the $\Delta \mathrm{I}$ of the Standards vs. $\mu$ moles of $\mathrm{H}_{2} \mathrm{O}_{2}$.

\section{Sample Determination:}

I Sample = I Test $-\mathbf{I}$ Test Blank (I: intensity of fluorescence).

Determine the $\mu$ moles of $\mathrm{H}_{2} \mathrm{O}_{2}$ liberated using the Standard Curve.

$$
\text { Enzyme activity Unit } / L(\mathrm{mU} / \mathrm{ml})=\frac{B}{10 * 0.03} * d f
$$

Where: 
B $\mu$ moles of $\mathrm{H}_{2} \mathrm{O}_{2}$ liberated according to standard curve.

$\mathrm{df}=$ Dilution factor.

$10=$ Time of assay in minutes.

$0.03=$ Volume (in milliliter) of enzyme used.

\section{Instrument}

Spectrofluorometer shimadzu RF- 5301.

\section{Optimization of the current method}

The concentration of 3-aminotriazole that was required to prevent the interference with catalase enzyme was investigated by utilizing RSM and using a BoxBehnken design $[17,18]$. The statistical parameters were estimated using the Design Expert Software (DES), Version 8.0.6, Stat-Ease Inc, USA. The enzymatic reaction of catalase reaction using (50 k-unit/L) was performed with different concentrations of 3aminotriazole and different periods of incubation time. The volume of reaction was adjusted to $1 \mathrm{~mL}$ and the catalase activity was calibrated using the peroxovanadate method as described by Hadwan and Ali [19]. The concentration of 3-aminotriazole, suitable time of incubation and thiamin concentration were carried out as independent variables (Table 1), and the sulfhydryl oxidase activity of the standard enzyme (30 IU) as a dependent variable. The second order polynomial equation was applied for arithmetic modeling to get the correlation between the independent and dependent variables (Eq. 1). The analysis and design of the RSM experiment were carried out using the software of Design Expert 12.

$\mathrm{Y}=\beta_{0}+\sum \beta_{\mathrm{i}} \mathrm{X}_{\mathrm{i}}+\sum \beta_{\mathrm{ii}} \mathrm{X}_{\mathrm{i}}^{2}+\sum \beta_{\mathrm{ij}} \mathrm{X}_{\mathrm{i}} \mathrm{X}_{\mathrm{j}}+\varepsilon(1)$

Where $\beta_{0}$ represent the intercept, $\beta_{\mathrm{i}}$ represents the linear coefficient, $\beta_{\mathrm{ii}}$ represents the quadratic coefficient and $\beta_{\mathrm{ij}}$ interaction coefficients. The residual is designed as $\varepsilon$. 
Table 2: Box-Behnken was designed to determine the optimal condition of the sulfhydryl oxidase activity. The 3-aminotriazole concentration, suitable time of incubation and thiamin concentration are also involved as independent variables as shown in Table 1, and the sulfhydryl activity of the standard enzyme (30 IU) as a dependent variable. The values were expressed as mean \pm SD $(n=3)$.

\begin{tabular}{|c|c|c|c|c|}
\hline \multirow[b]{2}{*}{ Run $^{a}$} & \multicolumn{3}{|c|}{ Independent variables } & \multirow{2}{*}{$\begin{array}{c}\text { Dependent } \\
\text { variable } \\
\text { Sulfhydryl } \\
\text { Oxidase } \\
\text { Activity }\end{array}$} \\
\hline & $\begin{array}{c}3- \\
\text { Aminotriazole } \\
(\mathrm{mM})\end{array}$ & $\begin{array}{l}\text { Incubation } \\
\text { Period } \\
\text { (min) }\end{array}$ & $\begin{array}{c}\text { Thiamin } \\
\text { Concentration } \\
(\mathrm{mM})\end{array}$ & \\
\hline 1 & 55 & 10 & 2.5 & 30 \\
\hline 2 & 55 & 20 & 1 & 3 \\
\hline 3 & 10 & 20 & 1.5 & 3 \\
\hline 4 & 100 & 1 & 5.5 & 10 \\
\hline 5 & 10 & 5.5 & 1 & 10 \\
\hline 6 & 100 & 10 & 5.5 & 29 \\
\hline 7 & 55 & 5.5 & 5.5 & 28 \\
\hline 8 & 55 & 1 & 10 & 2 \\
\hline 9 & 100 & 5.5 & 10 & 29 \\
\hline 10 & 55 & 5.5 & 5.5 & 28 \\
\hline 11 & 10 & 1 & 5.5 & 2 \\
\hline 12 & 55 & 10 & 5.5 & 28 \\
\hline 13 & 100 & 5.5 & 1 & 4 \\
\hline 14 & 55 & 5.5 & 5.5 & 28 \\
\hline 15 & 10 & 5.5 & 10 & 3 \\
\hline 16 & 55 & 1 & 1 & 3 \\
\hline 17 & 55 & 5.5 & 5.5 & 28 \\
\hline
\end{tabular}

${ }^{\text {a }}$ Random experiments creating by use Box-Behnken design.

\section{Statistical analysis}

Data analysis was achieved using SPSS 24 for Windows (SPSS Inc., Chicago, IL, USA). Data were expressed as mean, standard deviation (SD), and coefficient of variations $(\mathrm{CV})$.

\section{Results and discussion}

Although thiol compounds such as cysteine and glutathione change the precision of the peroxidase-mediated assessment of hydrogen peroxide concentration, a sensitive and precise fluorescence assay of the sulfhydryl oxidase can be developed. The method depends upon the formation of highly fluorescent thiochrome (excitation, $370 \mathrm{~nm}$; emission, $425 \mathrm{~nm}$ ) as a result of the oxidation of non-fluorescent thiamine by hydrogen peroxide/peroxidase system. Thiamine was established to be an appropriate fluorogen in the enzymatic reaction that contains $300 \mu \mathrm{M}$ reduced thiol compounds [16]. The formation of fluorescent thiochrome from the oxidation of non-fluorescent thiamine via the peroxide/ peroxidase or peroxide/peroxidase mimic system is frequently used to estimate thymine [20, 21] or to measure hydrogen peroxide [22]. 
Previous methods have used hemin, metal-porphyrin complex [23], hematin [24] or hemoglobin [22] as peroxidase mimics. The current method developed a new fluorometric assessment for sulfhydryl oxidase activity via hydrogen peroxide determination. The method utilizes a mixture of hematin (HT) and hemoglobin (HB) as mimetic peroxidase for stoichiometric reaction between thiamin and hydrogen peroxide. The results of the present study confirmed that the mixture of HT and HB is a good peroxidase mimic. The spectroscopic spectra of thiamine are shown in Figure 2.

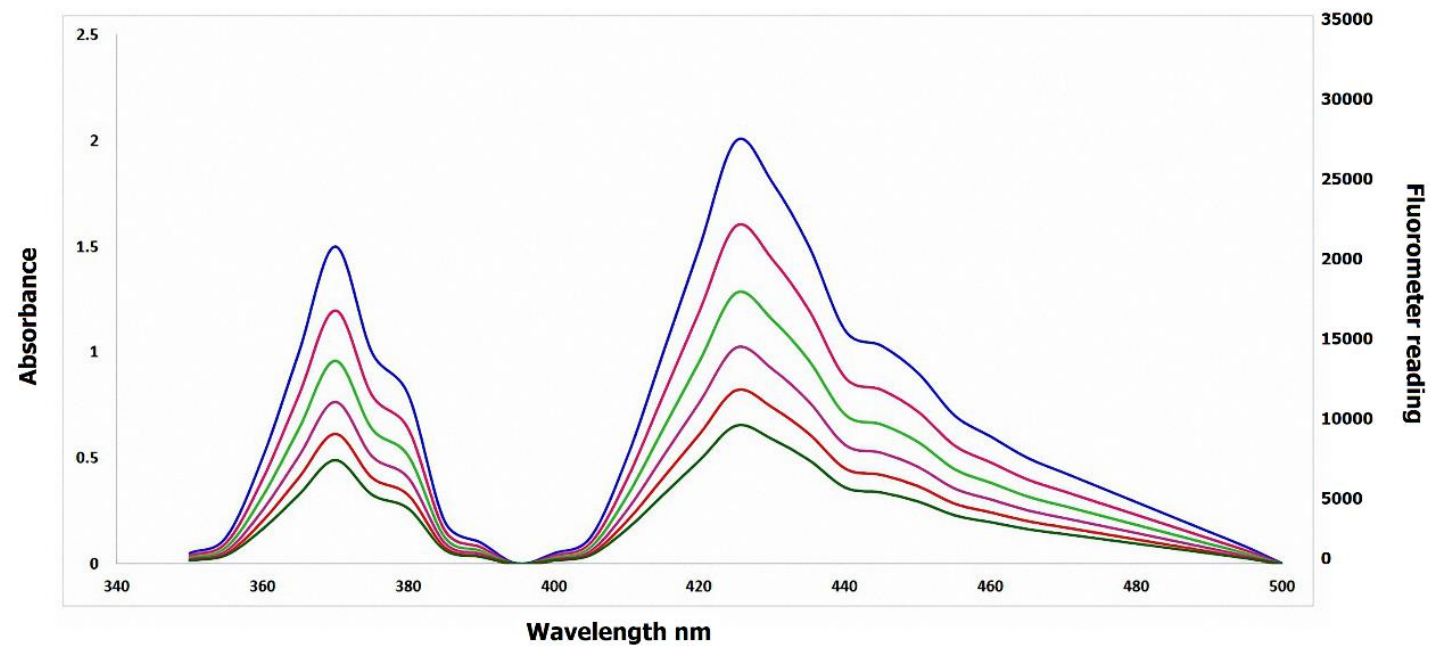

Figure 2: Emission spectra produced thiochrome. excitation spectra at $370 \mathrm{~nm}$ and emission spectra at $425 \mathrm{~nm}$.

The selective inhibitor of catalase (3-aminotriazole) was used to eliminate the expected interference which may arise from the existence of such an enzyme.

\section{Optimization of the current method}

In order to attain the best conditions, statistical processes were performed to the BBD $[17,18]$. The ANOVA analysis for the second order polynomial equations and results for the linear coefficients, quadratic coefficients and interaction coefficients are listed in Table 3. Statistical analysis shows that the postulated model has a significant fit of results. The resultant F-value (47.94) showed that the model was significant. The model terms were significant ( $\mathrm{p}=0.0001)$, according to additional findings. As a result, the SHO assay's ANOVA revealed that the actual correlation between the three independent variables of the proposed model was both appropriate for representation and highly significant. In order to examine the interaction effects of the three independent variables, contour graphs and three dimensional (3D) in the BBD were used. When the third component remained constant, the creation of the graphs at the midway level was reliant on a combination of two variables.

Figure 2 ( $a$ and $b$ ) shows the contour map of the impact of the independent variables on sulfhydryl oxidase activity. The results show a dependency on the 3 aminotriazol concentration, where it is found to be linear with $(\mathrm{p}<0.001)$ and quadratic with $(\mathrm{p}<0.05)$ effects and significantly affected by thiamine concentration. Other 
factors which participate in clarity involved the linear effect with $(\mathrm{p}<0.001)$ and quadratic effect with $(\mathrm{p}<0.01)$ of time.

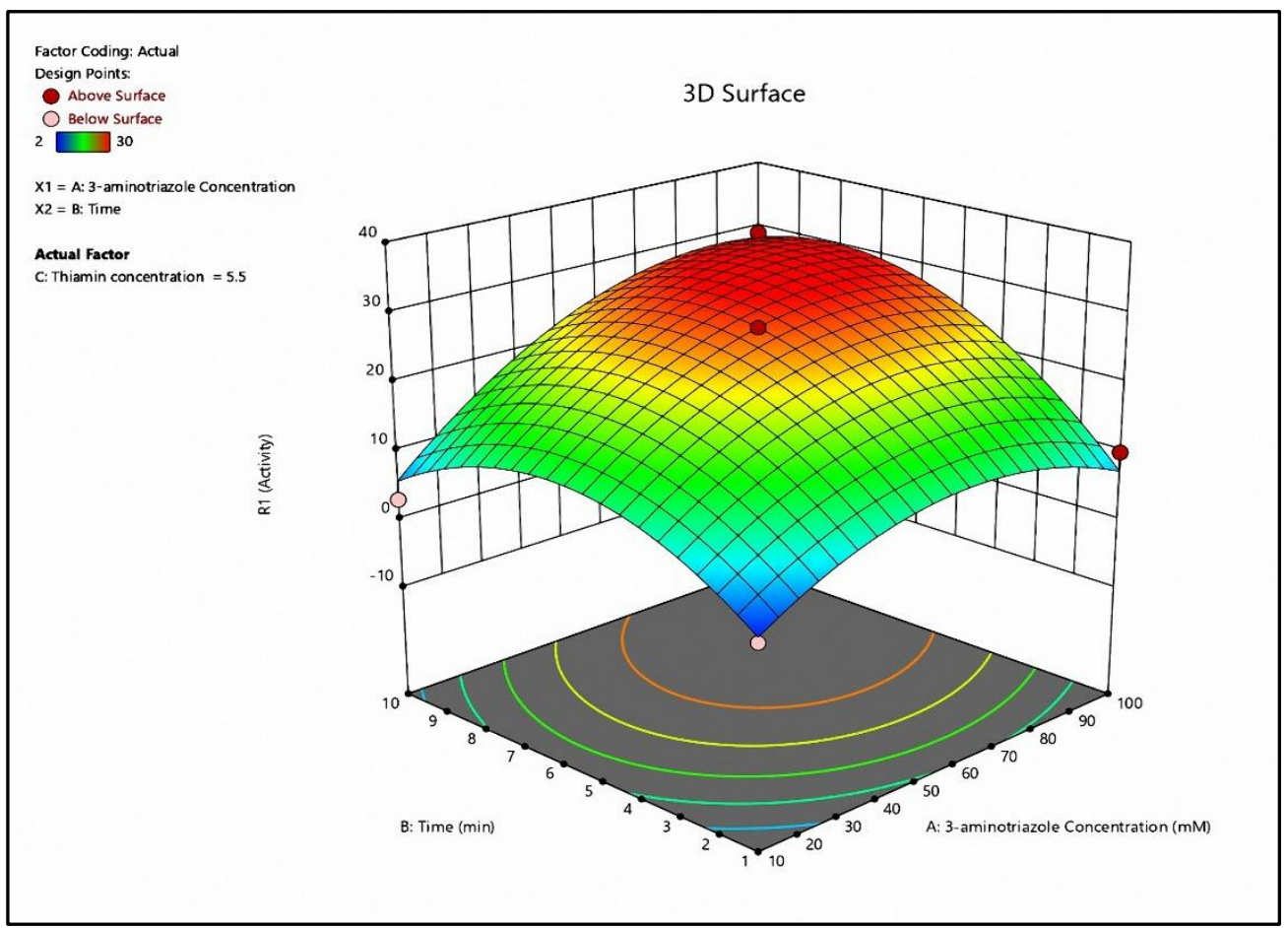

Figure 2-a: Response surface for activity of sulfhydryl oxidase as a function of 3aminotriazole concentration $(\mathrm{mM})$ and time $(\mathrm{min})\left(\right.$ at $\left.37^{\circ} \mathrm{C}\right)$.

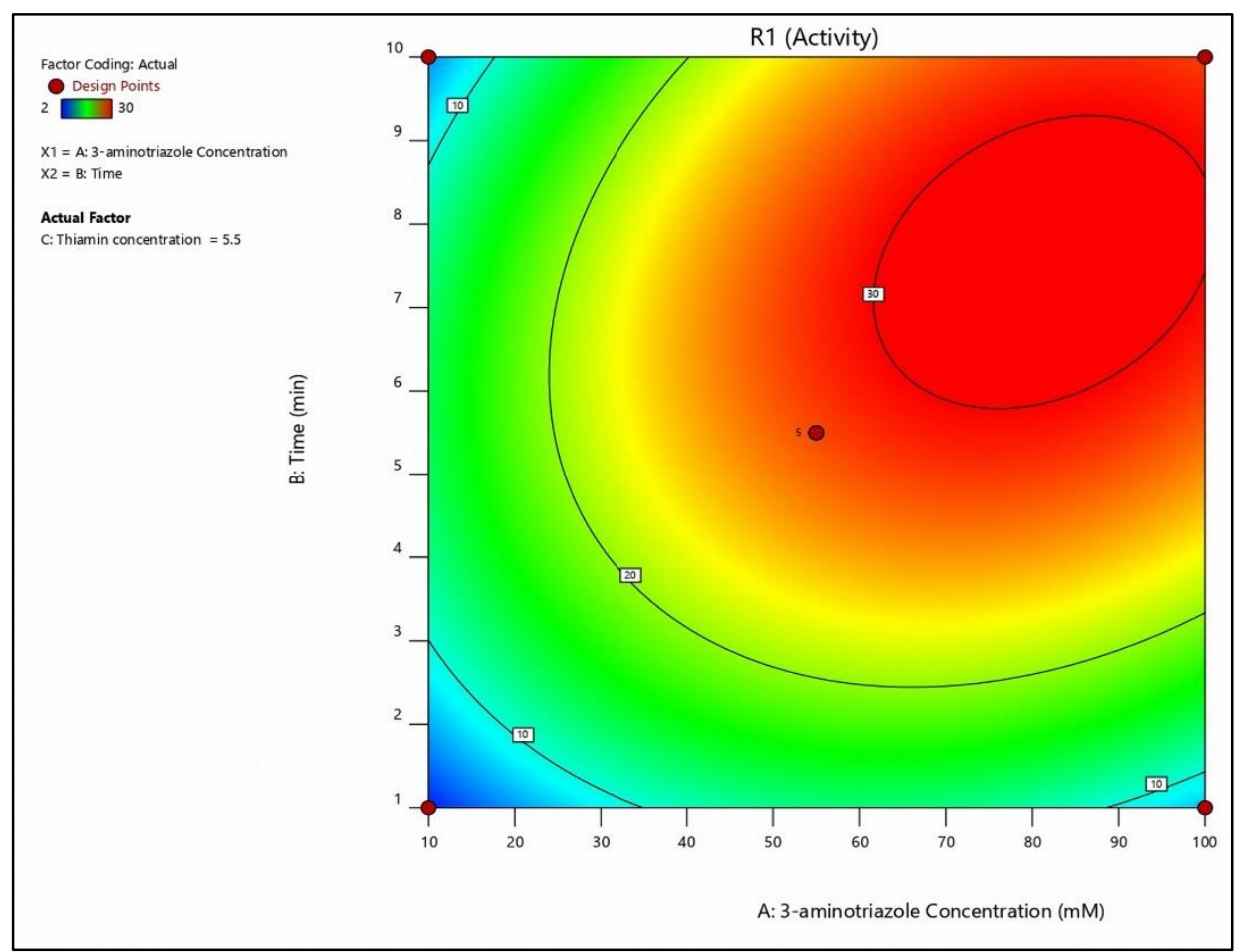

Figure 2-b: The contour plots of sulfhydryl oxidase activity as a function of the concentration of 3 -Aminotriazole $(\mathrm{mM})$ and time $(\mathrm{min})\left(\right.$ at $\left.37^{\circ} \mathrm{C}\right)$. 
Table 3: The ANOVA for quadratic studying model.

\begin{tabular}{|l|c|r|r|r|r|r|r|}
\hline Source & $\begin{array}{c}\text { Sum of } \\
\text { Squares }\end{array}$ & df & $\begin{array}{c}\text { Mean } \\
\text { Square }\end{array}$ & $\begin{array}{c}\text { f- } \\
\text { value }\end{array}$ & p-value & \\
\hline Model & 2496.56 & 9 & 277.40 & 47.94 & $<0.0001$ & significant \\
\hline A.3-aminotriazole Conc, & 364.50 & 1 & 364.50 & 63.00 & $<0.0001$ & \\
\hline B. Time & 288.00 & 1 & 288.00 & 49.78 & 0.0002 & \\
\hline C. Thiamin Conc. & 242.00 & 1 & 242.00 & 41.83 & 0.0003 & \\
\hline AB & 81.00 & 1 & 81.00 & 14.00 & 0.0072 & \\
\hline AC & 256.00 & 1 & 256.00 & 44.25 & 0.0003 & \\
\hline BC & 196.00 & 1 & 196.00 & 33.88 & 0.0006 & \\
\hline$A^{2}$ & 236.84 & 1 & 236.84 & 40.94 & 0.0004 & \\
\hline$B^{2}$ & 380.00 & 1 & 380.00 & 65.68 & $<0.0001$ & \\
\hline$C^{2}$ & 341.05 & 1 & 341.05 & 58.95 & 0.0001 & \\
\hline Residual & 40.50 & 7 & 5.79 & & & \\
\hline Pure Error & 0.0000 & 4 & 0.0000 & & & \\
\hline Lack of Fit & 40.50 & 3 & 13.50 & & & \\
\hline Cor Total & 2537.06 & 16 & & & & \\
\hline
\end{tabular}

Factor coding is Coded.

Summation of squares is Type III - Partial

The F-value of Model is 47.94 reveal that it's a significant model. This mean that only a $0.01 \%$ chance of F-value to be due to noise.

P-values $<0.05$ mean that the terms of model are significant. In present state A, B, C, AB, AC, BC, $\mathrm{A}^{2}, \mathrm{~B}^{2}, \mathrm{C}^{2}$ found to be a significant terms of model. Values $>0.1000$ mean that the terms of model are insignificant. If the terms of model are insignificant, the reduction of model may improve it.

The greatest SHO activity was achieved under optimal conditions, which were $55 \mathrm{mmol} \mathrm{L}{ }^{-1}$ concentration of 3-aminotriazole, $10 \mathrm{~min}$ suitable time of incubation, and $2.5 \mathrm{mmol} \mathrm{L}{ }^{-1}$ thiamin concentration. The highest activity was at $30 \mathrm{U} / \mathrm{L}$. The actual value was principally compatible with the predicted value, showing that the RSM analysis was consistent and fitted well with the practical conditions in the laboratory.

Several researchers focused studies on measuring hydrogen peroxide by using hemin, hematin, or cytochrome $\mathrm{c}$ as peroxidase mimics [25-28]. In the present assay, a new fluorometric method for assay sulfhydryl oxidase via $\mathrm{H}_{2} \mathrm{O}_{2}$ estimation is presented, that contains a mixture of hematin (HT) and hemoglobin (HB) used for mimetics peroxidase enzyme in fluorogenic reaction between thiamine and $\mathrm{H}_{2} \mathrm{O}_{2}$. Results obtained in the present study demonstrated that the mix of HB and HT is a promising peroxidase mimic.

Aminotriazole $(50 \mathrm{mM})$ is included in all subsequent assays of $\mathrm{SHO}$; this concentration is likely to be more than that necessary to inactivate the catalase present in seminal fluids. The increment of sulfhydryl oxidase activity after adding 50mMaminotriazole reaches up to $40 \%$ and stays constant with a higher concentration of this inhibitor. However, five minutes' incubation with $50 \mathrm{mM}$-aminotriazole allowed for 
adding one hundred k-units of catalase [obtained from Himedia (Product Code: TC037)] to the reaction mixture without any effect on the measured oxidase activity.

\section{Accuracy, reproducibility, selectivity and of the protocol}

A crude SHO enzyme was purified from hen egg white according to a method described by Hoober et al., [14]. It is used to compare the current method with other methods used to determine SHO activity. The results of the present study were compared with the previous colorimetric one [12], as listed in Table 4. The same specimens, substrate and buffer were utilized in two methods.

Table 4: Comparison between fluorometric and colorimetric method

\begin{tabular}{|l|l|}
\hline Specimens Numbers & 20 \\
\hline Mean of fluorometric method (nmol/ mg protein. min) & $31.41 \pm 3.55$ \\
\hline Mean of colorimetric method (nmol/ mg protein. min) & $30.88 \pm 2.2$ \\
\hline Regression coefficient A & 0.0115 \\
\hline Regression coefficient B & 0.9921 \\
\hline Correlation coefficient & 0.9911 \\
\hline
\end{tabular}

\section{Method application}

The present fluorometric method was applied to measure SHO activity in plasma of seminal fluid of 60 healthy fertile men with mean age of ( $33.5 \pm 5.5$ years) and 60 asthenzoospermic men with a mean age of $(35.5 \pm 4.5$ years $)$. The results are elucidated in Table 5.

Table 5: Sulfhydryl Oxidase activities in plasma of seminal fluid of healthy fertile and asthenzoospermic men.

\begin{tabular}{|l|l|l|}
\hline & Healthy controls & Asthenzoospermic patients \\
\hline $\begin{array}{l}\text { Sulfhydryl oxidase }(\mathrm{nmol} / \mathrm{mg} \\
\text { protein. min ) (mean } \pm \text { SD) }\end{array}$ & $70.82 \pm 4.03$ & $55.5 \pm 8.6$ \\
\hline
\end{tabular}

It is evident from the above that the results of this method can be used to assess the oxidative stress of seminal fluids. 


\section{Accuracy and precision of the protocol}

The accuracy of the whole method was determined by the recovery of $\mathrm{H}_{2} \mathrm{O}_{2}$ added to specimens which is detailed in Table 6.

Table 6: The recovery of $\mathrm{H}_{2} \mathrm{O}_{2}$

\begin{tabular}{|l|c|c|c|c|}
\hline Present in assay & $\begin{array}{c}\text { Equivalents of } \\
\mathrm{H}_{2} \mathrm{O}_{2}\end{array}$ & $\begin{array}{l}\text { Calculated } \\
\text { Activity U/liter }\end{array}$ & $\begin{array}{l}\text { Observed activity } \\
\mu \text { mol/liter }\end{array}$ & Recovery \% \\
\hline Pooled sample & ---- & ---- & 30 & ---- \\
\hline $\begin{array}{l}\text { Pooled sample }+ \\
\text { peroxide }\end{array}$ & 10 & 40 & 38 & 95 \\
\hline $\begin{array}{l}\text { Pooled sample }+ \\
\text { peroxide }\end{array}$ & 20 & 50 & 51 & 98 \\
\hline $\begin{array}{l}\text { Pooled sample }+ \\
\text { peroxide }\end{array}$ & 100 & 130 & 132 & 98.4 \\
\hline $\begin{array}{l}\text { Pooled sample }+ \\
\text { peroxide }\end{array}$ & 230 & 221 & 95.5 \\
\hline${ }^{2}$ mean of triplicate assay \\
\hline${ }^{\mathrm{b}}$ present as $\mathrm{H}_{2} \mathrm{O}_{2}$ \\
\hline
\end{tabular}

The precision of the assay is measured in-run on a single sample specimen and run over a period of three weeks with aliquots from the same sample pool but different reagent's preparations. The results are shown in Table 7.

Table 7: The precision of fluorometric method for determination of SHO activity

\begin{tabular}{|l|l|l|c|}
\hline & $\mathrm{N}$ & Mean $( \pm$ SD $) \mu \mathrm{mol} / \mathrm{l}$ & $\mathrm{CV} \%$ \\
\hline Within-run & 20 & $30.88 \pm 1.2$ & 3.8 \\
\hline Between-run & 20 & $28.8 \pm 1.5$ & 5 \\
\hline
\end{tabular}

The newly developed method presents many advantages over other methods to determine SHO activity includes; the small volume of the sample, relatively stable reagents of the method, simple handling with instrument and interference-free assay.

\section{Acknowledgment}

We thank all of our colleagues for their continuous encouragement and helpful scientific comments.

\section{Data availability}

All the data are available.

\section{Ethics approval and consent to participate.}

Ethics Committee (University of Babylon/ College of Science/ Iraq), Ref. no.: 3155 Date: 11/9/ 2019.

\section{Conflicts of Interest}

The authors declare no conflicts of interest or competing interests. 


\section{Funding sources}

None.

\section{Consent for publication}

The authors give their consent for the publication of identifiable details, which can include photograph(s) and/or videos and/or case history and/or details within the text ("Material") to be published in the Fluorescence Journal and Article. Therefore, anyone can read material published in the Journal.

\section{Authors' contributions}

The authors confirm contribution to the paper as follows: study conception and design: Mahmoud Hadwan; data collection: Abdul Razzaq S. Alsalman, Lamia A. Almashhedy, Abdulsamie H. Alta'ee, Mahmoud H. Hadwan, Asad M. Hadwan; analysis and interpretation of results: Abdul Razzaq S. Alsalman, Lamia A. Almashhedy, Abdulsamie H. Alta'ee, Mahmoud H. Hadwan; draft manuscript preparation: Abdul Razzaq S. Alsalman, Lamia A. Almashhedy, Abdulsamie H. Alta'ee, Mahmoud H. Hadwan, Asad M. Hadwan. All authors reviewed the results and approved the final version of the manuscript.

\section{References:}

1. Gào X, Wilsgaard T, Jansen EH, Xuan Y, Anusruti A, Brenner H, Schöttker B. Serum total thiol levels and the risk of lung, colorectal, breast and prostate cancer: A prospective case-cohort study. International journal of cancer. 2019 May 24.

2. Cremers CM, Jakob U. Oxidant sensing by reversible disulfide bond formation. Journal of Biological Chemistry. 2013 Sep 13;288(37):26489-96.

3. Sener S, Akbas A, Kilinc F, Baran P, Erel O, Aktas A. Thiol/disulfide homeostasis as a marker of oxidative stress in rosacea: a controlled spectrophotometric study. Cutaneous and ocular toxicology. 2019 Jan 2;38(1):55-8.

4. Solakhan M, Çiçek H, Orhan N, Yildirim M. Role of native Thiol, total Thiol and dynamic Disulphide in diagnosis of patient with prostate cancer and prostatitis. International braz $\mathrm{j}$ urol. 2019 Jun;45(3):495-502.

5. Alsalman AR, Almashhedy LA, Hadwan MH. Effect of Oral Zinc Supplementation on the Thiol Oxido-Reductive Index and Thiol-Related Enzymes in Seminal Plasma and Spermatozoa of Iraqi Asthenospermic Patients. Biological trace element research. 2018 Aug 1;184(2):340-9.

6. Chang TS, Morton B. Epididymal sulfhydryl oxidase: a sperm-protective enzyme from the male reproductive tract. Biochemical and biophysical research communications. 1975 Sep 2;66(1):309-15.

7. Erdogan AJ, Riemer J. Mitochondrial disulfide relay and its substrates: mechanisms in health and disease. Cell and tissue research. 2017 Jan 1;367(1):59-72.

8. Levitan A, Danon A, Lisowsky T. Unique features of plant mitochondrial sulfhydryl oxidase. Journal of Biological Chemistry. 2004 May 7;279(19):20002-8.

9. Faccio G, Kruus K, Buchert J, Saloheimo M. Secreted fungal sulfhydryl oxidases: sequence analysis and characterisation of a representative flavin-dependent enzyme from Aspergillus oryzae. BMC biochemistry. 2010 Dec;11(1):31.

10. Cornwall GA, Vindivich D, Tillman S, Chang TS. The effect of sulfhdryl oxidation on the morphology of immature hamster epididymal spermatozoa induced to acquire motility in vitro. Biology of reproduction. 1988 Aug 1;39(1):141-55. 
11. Ellman GL. Tissue sulfhydryl groups. Archives of biochemistry and biophysics. 1959 May 1;82(1):70-7.

12. Takamori K, Thorpe JM, Goldsmith LA. Skin sulfhydryl oxidase purification and some properties. Biochimica et Biophysica Acta (BBA)-Enzymology. 1980 Oct 7;615(2):309-23.

13. Raje S, Glynn NM, Thorpe C. A continuous fluorescence assay for sulfhydryl oxidase. Analytical biochemistry. 2002 Aug 15;307(2):266-72.

14. Hoober KL, Glynn NM, Burnside J, Coppock DL, Thorpe C. Homology between egg white sulfhydryl oxidase and quiescin Q6 defines a new class of flavin-linked sulfhydryl oxidases. Journal of Biological Chemistry. 1999 Nov 5;274(45):31759-62.

15. Kodali VK, Thorpe C. Quiescin sulfhydryl oxidase from Trypanosoma brucei: catalytic activity and mechanism of a QSOX family member with a single thioredoxin domain. Biochemistry. 2010 Feb 9;49(9):2075-85.

16. Hadwan MH, Almashhedy LA, Alsalman AR. Seminal sulfhydryl oxidase: Appropriate fluorometric assay for the examination of spermatozoa disorders. Biotechnol, an Indian journal. 2014;9(9: 376-382.

17. Bezerra MA, Santelli RE, Oliveira EP, Villar LS, Escaleira LA. Response surface methodology (RSM) as a tool for optimization in analytical chemistry. Talanta. 2008 Sep 15;76(5):965-77.

18. Lee WC, Yusof SA, Hamid NS, Baharin BS. Optimizing conditions for enzymatic clarification of banana juice using response surface methodology (RSM). Journal of food Engineering. 2006 Mar 1;73(1):55-63.

19. Hadwan MH, Ali SK. New spectrophotometric assay for assessments of catalase activity in biological samples. Analytical biochemistry. 2018 Feb 1;542:29-33.

20. Horwitz, W. (editor) Official Methods of Analysis of AOAC International, $17^{\text {th }}$ ed., Vol. 2., Thiamin Fluorometric Methods 942.23 Ch. 45 pp. 6-7, 957.17 Ch. 45 pp. 8-9, 2000.

21. Ellefson, W.C., Thiamin, In : Augustin, J., Klein, B.P., Beker, D.A., and enugopal, P.B. (editor) Methods of Vitamin Assay, $4^{\text {th }}$ ed., John Wiley \& Sons, Inc., New York, U.S.A., 349-363, 1985.

22. Chunli Xu and Zhujun Zhang (2001). Fluorescence Determination of Hydrogen Peroxide Using Hemoglobin as a Mimetic Enzyme of Peroxidase. Analytical Sciences 17,1449-1451.

23. C.-Q. Zhu, , D.-H. Li, H. Zheng, Q.-Z. Zhu, Q.-Y. Chen, and J.-G. Xu, (2000). Application of Manganese-Tetrasulfonatophthalocyanine as a New Mimetic Peroxidase in the Determination of Hydrogen Peroxide in Marine Surface Water Samples with $p$-Hydroxyphenylacetic Acid as a Substrate . Anal. Sci. 16,253-256.

24. J. Li, and P.K. Dasgupta (2000). Measurement of Atmospheric Hydrogen Peroxide and Hydroxymethyl Hydroperoxide with a Diffusion Scrubber and Light Emitting Diode-Liquid Core Waveguide-Based Fluorometry. Anal. Chem. 72, 5338-5347.

25. Rothe G, Valet G. Flow cytometric analysis of respiratory burst activity in phagocytes with hydroethidine and 2-77-dichlorofluorescin.J Leukoc Biol. 1990;47:440 - 448.

26. Cathcart R, Schwiers E, Ames BN. Detection of picomole levels of hydroperoxides using a fluorescent dichlorofluorescein assay. Anal Biochem. 1983;134:111-116.

27. LeBel CP, Ischiropoulos H, Bondy SC. Evaluation of the probe 2-7--dichlorofluorescin as an indicator of reactive oxygen species formation and oxidative stress.Chem Res Toxicol. 1992;5:227-231.

28. Huang X, Frenkel K, Klein CB, Costa M. Nickel induces increased oxidants in intact cultured mammalian cells as detected by dichlorofluorescein fluorescence.Toxicol Appl Pharmacol. $1993 ; 120: 29-36$. 


\section{Supplementary Files}

This is a list of supplementary files associated with this preprint. Click to download.

- ga.jpg 